\begin{tabular}{cc|c}
\hline Tar. Bil. Der. & Tarm Bilimleri Dergisi & Journal of Agricultural Sciences \\
& $\begin{array}{c}\text { Dergi web sayfası: } \\
\text { www.agri.ankara.edu.tr/dergi }\end{array}$ & Journal homepage: \\
& www.agri.ankara.edu.tr/journal
\end{tabular}

\title{
Isolation of Staphylococcus hominis from Cultured Gilthead Sea Bream (Sparus aurata L.) in Antalya Bay, Turkey
}

\author{
Mesut YILMAZa, Jale KORUN ${ }^{a}$, Mehmet GÖKOĞLU ${ }^{a}$, Yağmur Saadet ÇELİKa \\ ${ }^{a}$ Akdeniz University, Faculty of Fisheries, Campus, Antalya, TURKEY
}

\author{
ARTICLE INFO \\ Research Article DOI: 10.15832/ankutbd.539018 \\ Corresponding Author: Jale KORUN, Email: jalekorun@akdeniz.edu.tr, Tel: +90 (242) 3102018 \\ Received: 18 July 2017, Received in Revised Form: 06 November 2017, Accepted: 21 November 2017
}

\begin{abstract}
In this study, a disease case caused with $15 \%$ mortality on gilthead sea bream (Sparus aurata) which was cultured in the Antalya Bay in the Mediterranean coast of Turkey was investigated in July 2015. Lethargy, loss of equilibrium, petechae on the operculums and the dorsal part of the body, pillar of the gills were recorded in the diseased fish. Internally, ascites, splenomegaly and hemorrhages on the intestinal tissue and muscle were observed. Occurrence of parasite was not detected. According to the results of phenotypical test and 16S rDNA sequencing analysis, the isolated bacterial species was identified as Staphylococcus hominis. Histopathologically, hyperplasia of primary lamellae, lamellar telangiectasia, edema and hemorrhages on the gill arch, numerous melanomacrophage centers (MMCs) in the spleen tissue, vacuoler degeneration, necrose and hemorrhages in the liver, multifocal necrosis, and numerous MMC in the kidney were determined and hemorrhages in the tunica propria region of the intestine were observed. It was determined that he isolates showed different susceptibility against antimicrobial agents.
\end{abstract}

Keywords: Gilthead sea bream; Sparus aurata; Cage culture; Staphylococcus hominis

(C) Ankara Üniversitesi Ziraat Fakültesi

\section{Introduction}

Mediterranean aquaculture production has shown a continuous growth over the years. The production mainly includes two species, gilthead sea bream (Sparus aurata) and European sea bass (Dicentrarchus labrax). Because of economic importance of S. aurata, many studies, including nutrition (Andrew et al 2003), genetic (Alarcón et al 2004), biology (Noyo \& Lamas 1996), infectious and noninfectious disorders (Mladineo 2006; García-Rosada et al 2007; Beraldo \& Canavese 2011) were carried out.

A variety of infections affect farmed finfish species. These infections reduce the volume and quality of fish production. Bacterial infections, which are mostly affecting farmed sea bream include photobacteriosis, tenacibaculosis, pseudomonadiasis ('winter ulcer') and vibrosis (Toranzo et al 2005; Tanokhy 2013; Scarano et al 2014). The causative agents of the above mentioned infections are Gramnegative bacterial species. Among Gram-positive bacterial infections, Staphylococcal species, $S$. iniae (Zlotkin et al 1998), S. agalactiae (Evans et al 2002), S. epidermidis (Kubilay \& Ulukoy 2004), S. cobuii, S. lentus, S. schleiferi and S. warneri (Yiagnisis \& Athanassopoulou 2011) were isolated from sea bream. 
S. hominis was isolated from unpolluted marine waters, crab and crabmeat (Gunn \& Colwell 1983). Altuğ et al (2013) also reported $S$. hominis from unpolluted areas of the Sea of Marmara in Turkey. In addition, $S$. hominis were isolated from the diseased farmed sea bass fry (Yiagnisis \& Athanassopoulou 2011).

This study describes the first record of Staphylococcus hominis from cultured gilthead sea bream (Sparus aurata) in the Antalya Bay. S. hominis was isolated as the causative agent of the disease and identified by $16 \mathrm{~S}$ rRNA sequence and its histopathology are determined.

\section{Material and Methods}

\subsection{Fish sampling and clinical examination}

This study was carried on a commercial firm in the Antalya Bay, Eastern Mediterranean Sea, Turkey during spring and summer seasons (from May to November) in 2015. Twenty fish samples were collected from each sampling. Totally 120 fish were randomly collected from floating cages. The water temperatures during this period fluctuated $24{ }^{\circ} \mathrm{C}$ between $28{ }^{\circ} \mathrm{C}$. The weights of the fish ranged from $150 \mathrm{~g}$ to $240 \mathrm{~g}$. In July, a disease outbreak with $15 \%$ fish losses occurred in the farm. The affected fish were brought alive and transported back to the Akdeniz University Faculty of Fisheries (AUSUF) research laboratory in plastic bags containing aerated sea water from the cage environment. After fish transporting, the fish were deep anesthetized with 2-Phenoxyethanol at $300 \mathrm{mg} \mathrm{L}^{-1}$ consantration in sea water for $15 \mathrm{~min}$ before necropsy and examined for the external signs on the body surface. Then, the samples were necropsied and internal findings of them were noticed. The procedures were reviewed and approved by the Akdeniz University Local Committee on Animal Research Ethics. Number: 2015.03.06.

\subsection{Parasitological examination}

Standard parasitological methods for examination of fish were applied (Collins 1993). Smear preparations on glass slides from skin and gill lamellae were prepared and examined under light microscope. Then, organs (stomach, intestine, liver, kidney, and spleen) were removed and placed in petri dishes containing sterilized saline water and examined under light microscope.

\subsection{Bacteriological study}

For bacterial isolation, samples taken from liver, kidney, and spleen of moribund gilthead sea bream were inoculated on brain heart infusion (BHI) agar with $1.5-\% \mathrm{NaCl}$. Cultures were incubated at $26 \pm 2$ ${ }^{\circ} \mathrm{C}$ for $72 \mathrm{~h}$. After incubation, bacterial colonies were subcultured and pure cultures of the colonies were subjected to conventional tests including Gram-staining, motility, cytochrome oxidase and catalase for biochemical identification by following the procedures of Seeley et al (1991) and Austin \& Austin (2012). 16S rDNA studies were also conducted on that pure cultures.

\subsection{Antimicrobial susceptibility testing}

In vitro susceptibility testing of the strains was carried out by using the disc agar diffusion method according to the CLSI (M42-A) (2006). The tests were performed in duplicates. The following antimicrobial agents $(\mu \mathrm{g})$ were employed: ampicillin (10), bacitracin (0.04), chloramphenicol (30), erythromycin (15), flumequine (30), kanamycin (30), nalidixic acid (30), oxolinic acid (2), oxytetracycline (30), streptomycin (10), sulfamethoxazole (25), tetracycline (30) and trimethoprim (5).

\subsection{Nucleic acid isolation}

A typical colony from pure culture was grown in 5 $\mathrm{mL}$ of Nutrient broth (NB) with $1.5 \% \mathrm{NaCl}$ at 26 ${ }^{\circ} \mathrm{C}$ for overnight. $1.5 \mathrm{~mL}$ of this culture was used for bacterial DNA extraction using DNA extraction kit (Thermo Scientific) in accordance with the manufacturer's Gram-positive bacterial DNA isolation instructions. Bacterial genomic DNA was eluted by $10 \mathrm{mM}$ Tris-EDTA buffer up to volume $200 \mu \mathrm{L}$ and stored at $-20{ }^{\circ} \mathrm{C}$ until used.

\subsection{PCR assay}

Isolates from the diseased fish samples were identified by using Gram staining, colony morphology and biochemical tests. They were 
further identified with 16S rDNA gene sequence analysis. The polymerase chain reaction (PCR) has provided for the detection. The universal primers, B27F (5'-AGAGTTTGATCCTGGCTCAG-3') and U1492R (5'-GGTTACCTTGTTACGACTT-3'), were used for amplification of the 16S ribosomal DNA gene (Liu et al 2013; Liu et al 2014). $5 \mu \mathrm{L}$ of genomic DNA solution in Tris-EDTA buffer was added to 45 $\mu \mathrm{L}$ of a PCR mixture consisting $2 \mathrm{X}$ mix (Qiagen), 1 $\mu \mathrm{L}(10 \mathrm{nmol})$ of each primers and sterile Milliporequality water added up to $50 \mu \mathrm{L}$. Amplification was carried out in a thermocycler (Kyratec SC-200), iniated by $10 \mathrm{~min}$ of denaturation at $95{ }^{\circ} \mathrm{C}$ and then carried out for 35 PCR cycles of which each consists of $45 \mathrm{sec}$ of denaturation at $95^{\circ} \mathrm{C}, 45 \mathrm{sec}$ of annealing at $60{ }^{\circ} \mathrm{C}$, and $2.5 \mathrm{~min}$ extension at $72^{\circ} \mathrm{C}$. The reaction was lasted with heating at $72{ }^{\circ} \mathrm{C}$ for $10 \mathrm{~min}$ after the last cycle. A negative control with all the reaction components except template DNA was included with each test run.

\subsection{Molecular characterization, gel extraction and identification of the isolate by BLASTN}

Twenty $\mu \mathrm{L}$ of the reaction mixture was analyzed by submarine gel electrophoresis in $1 \%$ agarose (Bioron) at $8 \mathrm{~V} \mathrm{~cm}^{-1} .1 \mathrm{~kb}$ DNA ladder (GeneRuler) was used for molecular characterization of the PCR product. To extract amplicons from the gel extraction kit (Macherey-Nagel) was used by following the protocol of the manufacturer. After that PCR products were sequenced by Macrogen Inc. The sequences were subjected to BioEdit V7.2.5. program (Hall 1999) to assemble the revers and forward fragments then compared to $16 \mathrm{~S}$ rDNA sequences in the GenBank database by using the BLASTN algorithm (Chu \& Lu 2005; Liu et al 2013; Liu et al 2014).

\subsection{Histopathological study}

Tissue samples from gills and internal organs were fixed in $10 \%$ buffered formalin solution for routine histopathological examination (Culling 1963). The fixed tissue samples washed in tap water overnight and dehydrated in the ascending concentrations of ethanol. After dehydration, tissue samples were cleared in xylene and sectioned at $5 \mu \mathrm{m}$. Then, the sections were stained with hematoxylin and eosin $(\mathrm{H} \& \mathrm{E})$.

\section{Results and Discussion}

\subsection{Clinical findings}

The moribund fish were lethargic. They showed petechae on the operculums and dorsal parts of their body surfaces. Other signs included hemorrhages on the intestinal wall and muscle, pale liver and enlarged spleen. The spleen was also in cherry red color. Yiagnisis \& Athanassopoulou (2011) isolated $S$. hominis from a bacterial survey study of the wild and farmed marine fish species in Greece. The authors reported that affected fish had anorexia and the generalized hemorrhagic septicemia including visceral petechation. Our findings were similar to those reported by Yiagnisis \& Athanassopoulou (2011).

\subsection{Parasitological findings, bacterial isolation and identification}

Ectoparasites or endoparasites were not detected in fish. As a result of bacteriological studies, whitish to creamy colored bacterial colonies on BHI agar with $1.5 \% \mathrm{NaCl}$ were observed at $26 \pm 2{ }^{\circ} \mathrm{C}$ for $72 \mathrm{~h}$. These bacterial colonies were subcultured and the strains from these colonies were tested biochemical tests. The isolate was nonmotile, Gram-positive, facultatively fermentative, cytochrome oxidase negative and coagulase (rabbit plasma) negative. $16 \mathrm{~S}$ rDNA sequences of the isolated strains were compared with the GenBank database by using the BLASTN. The closest matches obtained with Staphylococcus hominis (GenBank accession number KF254627.1; maximal score 2636, E value 0.0 , and maximal identity 99\% (1429/1430)). Most Staphylococci, including S. epidermis, S. hominis and $S$. warneri from fish as coagulase-negative were reported (Ahmet et al 2011). S. hominis isolated in this study was Gram-positive, clusters, cytochrome oxidase and coagulase negative and facultatively fermentative. Our own biochemical test results for $S$. hominis agreed with those of Schleifer \& Bell (2009) and Ahmet et al (2011) except mannitol and arabinose test results. 


\subsection{Results of antimicrobial susceptibility testing}

Staphylococcus hominis showed varying susceptibility to the antimicrobial agents which were employed in this test. It was highly sensitive to chloramphenicol, tetracycline, streptomycin, oxytetracycline, kanamycin, trimethoprim and erythromycin (more than inhibition zone of $25 \mathrm{~mm}$ ) except bacitracin (the inhibition zone $<20 \mathrm{~mm}$ ) while it showed intermediate resistance to ampicillin. Bacterial infections in fish culture are important, and for this reason, agents are widely used for treatment; however, a few reports on antimicrobial susceptibility of $S$. hominis. Uddin et al (2013) reported that the species isolated from black tiger shrimp (Penaeus monodon) showed resistance to ampicillin and erythromycin. But,
S. hominis was found sensitive against the above mentioned antibiotics and also others in this study.

\subsection{Results of histopathological examination}

The histopathological examination of tissues of gilthead sea bream revealed that the gills demonstrated hyperplasia of the primary lamellae (Figure 1a), lamellar telangiectasia (Figure 1b), and the gill arch showed edema and hemorrhages (Figure 1c). The spleen showed numerous of melanomacrophage centers (MMCs) (Figure 2a), and activations of MMCs were detected. These centers were well defined, numerous and dark brown colored. Splenic congestion was also observed (Figure 2b). Basophilic areas with bacterial colonies were observed (Figure 2b). Focal empty shaped

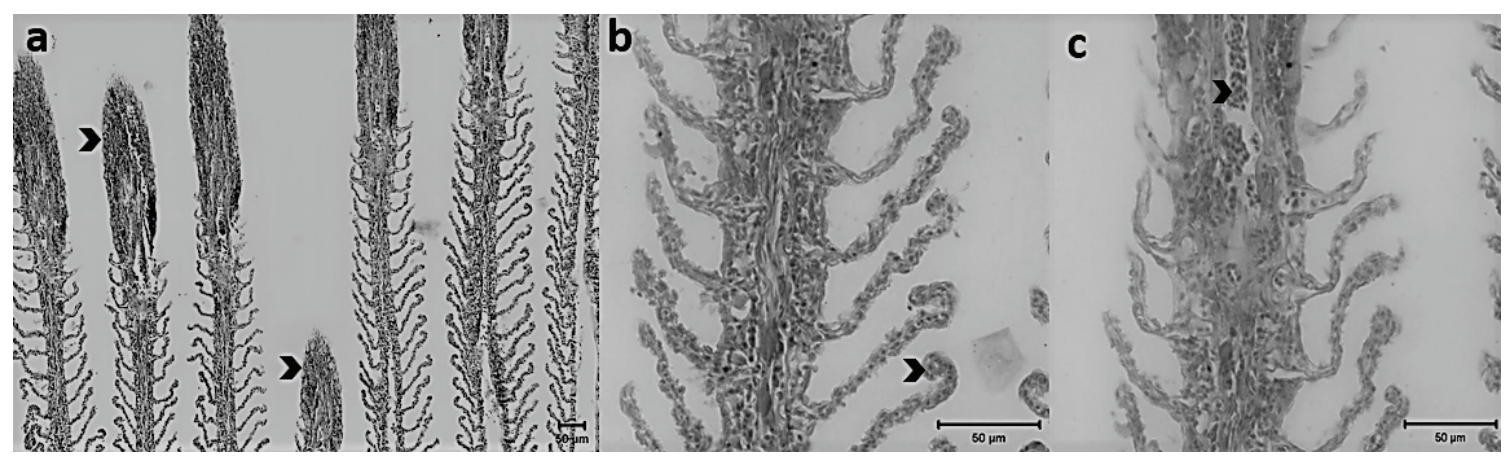

Figure 1- Gill of diseased fish (H+E). a, Hyperplastic area rich in secretory cells in the primary lamellae (arrowhead); b, Lamellar telangiectasia (arrowhead); c, the gill arch showing edema and hemorrhages (arrowhead) (H \& E)

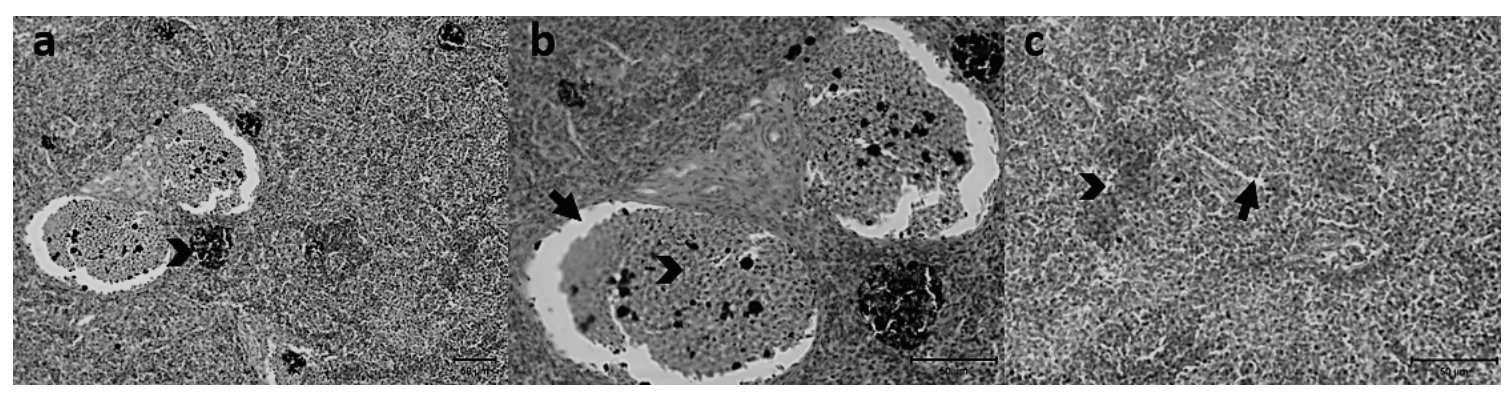

Figure 2- Spleen of diseased fish $(\mathrm{H}+\mathrm{E})$. a, activation of melanomacrophage centers (MMCs) (arrowhead); b, congested blood vessels (arrow) and basophilic areas with bacterial colonies (arrowhead); c, focal empty spaces (arrow) due to depletion, necrosis and lysis of hematopoietic elements and focal hemorrhages (arrowhead) (H \& E) 
spaces in the spleen due to depletion, necrosis, loss of hematopoietic elements and focal hemorrhages in the spleen tissue were evident (Figure 2c). The liver showed vascular degeneration of hepatocytes, hepatocytic necrosis and hemorrhage (Figure 3a). Multifocal areas of tubular and interstitial necrosis and hemorrhages, heavy depositions in the MMCs in kidney (Figure 3b) were observed. Hemorrhages (Figure 3c) in tunica propria of the intestine, villous atrophy and also depletion of the intestinal mucosa were evident. Histopathological examinations of tissues showed activations of MMCs, necrosis and lysis of hematopoietic elements and hemorrhages in the spleen, liver and kidney.

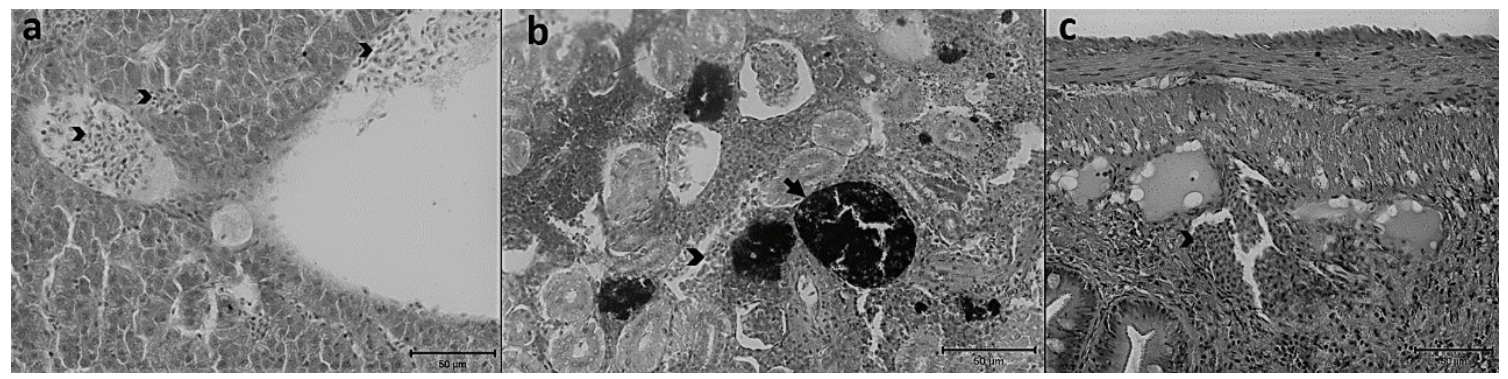

Figure 3- a, Hepatocytic necrosis and hemorrhages in the liver; $b$, hemorrhage (arrowhead) and heavy deposition in the MMcs (arrow) in the kidney; c, hemorrhages (arrowhead) in tunica propria of the intestine (H \& E)

\section{Conclusions}

Staphylococcus hominis was first isolated and identified from the cultured gilthead sea bream (S. aurata) from Antalya Bay (Turkey) in this study. High water temperature above optimal growth temperature $\left(22-25^{\circ} \mathrm{C}\right)$ for gilthead sea bream and handling could be two reasons to begin disease outbreak. Histopathological changes were detected on tissues of affected fish. To better understand virulence mechanisms of Staphylococcus hominis on different fish species, including Sparus aurata, further studies should be carried on under controlled conditions.

\section{References}

Ahmet A, Rab A, Khan F \& Qasim M (2011). Identification and antibiotic susceptibility of bacterial pathogens in rainbow trout at Juglote, Gilgit, Baltistan. Punjab University Journal of Zoology 26: 133-137

Alarcón J A, Magoulas A, Geogakopoulos T, Zouros E \& Alvarez M C (2004). Genetic comparison of wild and cultivated European populations of the gilthead sea bream (Sparus aurata). Aquaculture 230: 65-80
Altuğ G, Çardak M, Çiftçi P S \& Gürün S (2013). First records and microgeographical variations of cultarable heterotrophic bacteria in an inner sea (the Sea of Marmara) between the Mediterranean and the Black Sea, Turkey. Turkish Journal of Biology 37: 184-190

Andrew J E, Bégout-Anras M L, Kadri S, Holm J \& Huntingford F A (2003). Feeding responses of hatchery-reared gilthead sea bream (Sparus aurata L.) to a commercial diet and natural prey items. Marine and Freshwater Behaviour and Physiology 36: 77-86

Austin B \& Austin D (2012). Bacterial Fish Pathogens. Diseases of Farmed and Wild Fish, Springer ScienceBusiness Media, England

Beraldo P \& Canavese B (2011). Recovery of opercular anomalies in gilthead sea bream, Sparus aurata L: morphological and morphometric analysis. Journal of Fish Diseases 34: 21-30

Chu W-H \& Lu C P (2005). Multiplex pcr assay for the detection of pathogenic Aeromonas hydrophila. Journal of Fish Diseases 28: 437-441

CLSI (M42-A) (2006). Clinical and Laboratory Standards Institute, Methods for antimicrobial disk susceptibility testing of bacteria isolated from aquatic animals; approved guideline. Pennsylvania 
Collins R (1993). Principles of diagnosis.In: L Brown (Ed), Aquaculture for Veterinarians: Fish Husbandry and Medicine, Pergamon Press, Oxford, pp. 69-89

Culling C F A (1963). Handbook of Histopathological Techniques, Butter Worth Co. Ltd., London, England, $553 \mathrm{pp}$

Evans J J, Klesius P H, Gilbert P M, Shoemaker C A, Al Sarawi M A, Lansberg J, Duremdez R, Al Marzouk A \& Al Zenki S (2002). Characterization of ß-haemolytic Streptococcus agalactiae in cultured sea bream, Sparus aurata L., and wild mullet, Liza klunzingeri (Day), in Kuwait. Journal of Fish Diseases 25: 505513

García-Rosada E, Cano I, Martin-Antonio B, Labella A, Manchado M, Alonso M C \& Castro D (2007). Co-occurence of viral and bacterial pathogens in disease outbreaks affecting newly cultured sparid fish. International Microbiology 10: 193-199

Gunn B A \& Colwell R R (1983). Numerical taxonomy of Staphylococci isolated from the marine environment. International Journal of Systematic Bacteriology 33: 751-759

Hall T A (1999). BioEdit: a user-friendly biological alignment editor and analysis program for Windows 95/98/NT

Kubilay A \& Uluköy G (2004). First isolation of Staphylococcus epidermidis from cultured gilthead sea bream (Sparus aurata) in Turkey. Bulletin of the European Association of Fish Pathologists 24: 137143

Liu P Y, Lin C F, Tung K C, Shyu C L, Wu M J, Liu J W, Chang C S, Chan K W, Huang J A \& Shi Z Y (2013). Clinical and microbiological features of Shewanella bacterimia in patients with hepatobiliary disease. Internal Medicine 52: 431-438

Liu P Y, Shi Z Y, Shyu C L, Wu Z K, Lai K L, Chang C Y, Chen Y J, Huang J A, Mao Y C \& Tung K C (2014). Cobra bite wound infection caused by Shewanella algae. International Journal of Infectious Diseases: e11-e12
Mladineo I (2006). Check list of the parasitofauna in Adriatic sea cage-reared fish. Acta Veterinaria Belgrade 56: 285-292

Noyo M \& Lamas J (1996). Morphology and histochemistry of a PAS-positive granular cell in the gills of the gilthead sea bream, Sparus aurata L. Journal of Anatomy 189: 439-443

Scarano C, Spanu C, Ziino G, Pedonese F, Dalmasso A, Spanu V, Virdis S \& De Santis E P L (2014). Antibiotic resistance of Vibrio species isolated from Sparus aurata reared in Italian mariculture. New Microbiologica 37: 327-329

Schleifer K H \& Bell J A (2009). Family VIII. Staphylococcaceae fam. nov. In: G Garrity, D Jones, N R Krieg, W Ludwig, F A Rainey, K H Schleifer \& W B Whitman (Eds), Bergey's Manual of Systematic Bacteriology, Springer-Verlag, New York, pp. 392

Seeley W, Vandemark P J \& Lee J L (1991). Microbes in Action, A Laboratory Manual Microbiology, W H Freeman and Company, New York

Tanokhy M (2013). Some study on bacterial infection in some cultured marine fish. Journal of the Arabian Aquaculture Society 8: 163-178

Toranzo A E, Magariños B \& Romalde J L (2005). A review of the main bacterial fish diseases in mariculture systems. Aquaculture 246: 37-61

Uddin G M N, Larsen M H, Guardabassi L \& Dalsgaard A (2013). Bacterial flora and antimicrobial resistance in raw frozen cultured seafood imported to Denmark. Journal of Food Protection 76: 490-499

Yiagnisis M \& Athanassopoulou F (2011). Bacteria isolated from diseased wild and farmed marine fish in Greece.F Aral (Ed), Recent Advances in Fish Farms pp. $153-168$

Zlotkin A, Hershko H \& Eldar A (1998). Possible transmission of Streptococcus iniae from wild fish to cultured marine fish. Applied and Enviromental Microbiology 64: 4065-4067 